\title{
The Role Analysis of State Law in Initiating the Bankruptcy Procedure
}

\section{PhD Candidate Ervin Bacaj ${ }^{1}$}

\author{
Prof Dr Ismail Zejneli2 \\ Prof. Dr. Alba Dumi ${ }^{3}$ \\ ${ }^{1}$ Department of Law and State Moscow University" University of Vlore, Albania, Moscow Russia \\ ${ }^{2}$ Academic Pro Rector of Law Faculty SEEU University Tetovo Macedonia \\ 3Dean of Graduated School, Management Department" Economy Faculty University of Vlore, Albania \\ Email: alba.besi12@gmail.com
}

\section{Doi:10.5901/ajis.2015.v4n3s1p476}

\section{Abstract}

\begin{abstract}
The goal of any state is its legal order implemented spontaneously and without violations of legal norms that regulate the specific legal substances, implementation of a legal system designed to rate the actual legal relations of legal entities, whether legal entities means behavior own initiative and spontaneous voluntary legal entities in accordance with legal norms. In the opposite case it lacks efficiency of implementation of legal norms of the legal system and in the scene is presented the mechanism of efficiency and secondary measures, which means the realization of their violent, that in the scene are presented the procedures as in reality is civil procedure, execution and bankruptcy procedures as violent procedures in legal theory for implementing the rule of law to exist and apply valid legal norms of the legal system.Legal order of each state is based on the strong ties between its legal norms (normative element of the legal order) and actual behavior of people under them normative (factual element of the legal order), the dynamism of its legal order begins with the creation of legal norms and ends with their implementation between the behavior of people in legal relations
\end{abstract}

Keywords: Legal norms, legal theory, legal system, bankruptcy, the measure of bankruptcy procedure.

\section{Introduction}

Bankruptcy as a legal institution was present in Roman law, in this aspect of insolvency law is considered legal and protective measure that has been in relation to the creditor against the debtor or debtors known as si mision in bona dhe si cession bonorum.

In mission in bona the creditor goal was to confiscate the property of the debtor or the debtor by the creditor to realize the sale confiscation of seized items and to meet its requirements through the sale of confiscated items, through cession bonorum a debtor in voluntary order he has submitted wealth creditor itself in order to fulfill the obligations that have arisen in relations binding.

\subsection{Overview of Bankruptcy}

In this regard therefore the bankruptcy has been important and necessary for the economic and legal circulation of the reports that have been created between the subjects of the law, after a certain period, it is necessary that will be realized as such protection and and by what rules and actions to protect such a right and which bodies will be responsible for protecting the rights of creditors? Thus arises then the failure procedure and the authority to protect the rights of creditors is the only authority body that protects all rights of law subjects such as courts.

Taking into consideration our positive law and its development thanks to the recent period of failure law and its proceedings and judicial practice of the Republic of Macedonia has taken important steps in this field.

The Bankruptcy law, the content and the way is developed the failure procedure consists on bases of socioeconomic aspects and of the general legal system of the Republic of Macedonia. With this law is regulated, the purpose and conditions of the opening of failure proceedings, the failure procedure bodies, management and disposition which goes into failure measure, meeting the requirements of creditors in failiure proceedings, the legal effects of the opening of bankruptcy proceedings, the personal direction, other duty relief, specific forms of insolvency, and other matters relating 
to failure.$^{1}$ Through this law are regulated form and content on how to develop the procedure of failure and all the elements and conditions for an efficient development and right one, regarding to failure context.In this context we must emphasize that against the general rules of Bankruptcy procedure and special rules exist for the development of the insolvency proceedings as well as materialistic nature and even of formal legal.By this law is regulated and opening of the failure proceedings against the property of physical and legal persons, with all the legislators have foreseen and rules that can be exercised as of the insolvency proceedings to legal persons, including law as individual traders. Major changes and reforms regarding insolvency began in 1997 as a transistor with system changes that need to get such a step in order not to remain processes at the crossroads. A great focus is given to lawmakers under current law the previous laws is set as the division of failure measure but also to physical changes are made to the legislation planned and other ways of proceeding ways of reorganizing the alternative preventive measures for the salvation of companies rom failure.

\section{Literature Review and Hypotheses}

If it is achieved to be viewed the failure from the standpoint of the definition of insolvency within the legal aspect commercial companies can be defined as a form of termination of legal subjectivity of a company in economic failure outlook presented as market instrument through which companies create efficient selection or that may exist in the market as opposed to those which are not efficient and are not rentable in the market.Legal nature of the failure procedure in theory has different views regarding failure as legal branch, attitudes in theory are as to the definition of failure as a separate civil procedure, while the other approach is related to the failure proceedings which can participate in the contentious procedure as assigning special progressive procedure.

Despite the theoretical approaches we can conclude that the failure procedure has a special purpose in the context of the state's judicial legislation with the aim of protecting creditors by the debtors and the main goal is fulfillment of these requirements. However, these theories appear the oldest literature of the classical part of failure proceedings. ${ }^{2}$ Today, one can safely conclude that the definition of such failure procedure as a means of enforcement against violent and property of debtors and enforcement tool is ungrounded and not functional as a concept in legal terms.

\section{Research Goal}

Failure proceedings is beginning the execution procedure against all of the assets of the bankruptcy debtor in bankruptcy creditors benefit everyone. ${ }^{3}$ Failure proceedings, as a general procedure of execution has priority over the execution procedure.A feature appearing as theoretical between Bankruptcy proceedings and other classic theories in the face of violent about failure is that with the beginning failure procedure, it could not be initiated enforcement proceedings in all previous actions lie in the same report which can be filed in failure measure that means in failure procedure.With the opening of failure procedure,the failed creditors can not demand their insurance claims against the bankruptcy debtor, other procedures such as the execution procedure performance and security procedures with the beginning of these proceedings,these procedure are interrupted under the rule of law. Bankruptcy proceedings unlike bankruptcy proceedings as a means of execution procedures executing always is held against particular persons with special needs who may request the debtor to meet the demand of the creditor, while the insolvency procedure to all their demands are not creditors. (Dumi A "Analyze of SME and Management" Tirana 2015, pp 239)

They address their requirements in order separator but all the requirements jointly submit the failure measure.Based on the law on the procedure of insolvency of the Republic of Macedonia are regulated in accordance to the recommendations of the European legislation, which under this law are regulated way on how initiated bankruptcy proceedings. Persons who are authorized to initiate bankruptcy proceedings where under the law is provided; the organs of bankruptcy proceedings, management and disposition that goes into bankruptcy measure, meeting the requirements of creditors in bankruptcy proceedings, legal effects with the opening of bankruptcy proceedings, reorganization plan, personal direction, the release of other obligations, bankruptcy procedures specific personal status of traders, and bankruptcy proceedings with foreign element and other issues. ${ }^{4}$

\footnotetext{
${ }^{1}$ D. Kostovski. "The failure law with commentary and judicial practice" p.1. Skopje 2014

2 The same point

${ }^{3}$ A. Janevski. "Law enforcement" Skopje 2011 p.7

${ }^{4}$ Law on failure Section 1. "Official Newspaper of RM" no: 34/06
} 


\section{Sample and Data Collections}

In accordance with the legislation of the Republic of Macedonia is regulated bankruptcy proceedings that at the beginning of pluralism where its beginnings bankruptcy procedure law was within the law on the organization of business companies, then in 96/97 with creation time of the law on bankruptcy, then supplementing and amending 06/07 and last time the amendment of the law on the procedure of insolvency in 2014.

\subsection{The notion of Bankruptcy Procedure}

Bankruptcy is considered a judicial order of termination of commercial companies if they are operating at a loss and are not able to make the implementation of their demands. ${ }^{5}$ In these cases is considered that financially debtor is unable to perform duties within certain achievements, in those cases where the debtor does not meet the demands gold of creditors collectively jointly creditors may initiate failure proceedings, who at the beginning of failure proceedings specifically in failure measure which takes place in the first stadium's procedure is considered the request for failure proceedings can not be entered as debtor, and open trial and the wealth of the company finds a clear step in isolvency and under this failure measure and property which the company is available, through the failure judge hrough experts will make an evaluation of property and on the basis of this capital will fullfil the requirements of failed creditors. (Dumi A "Analyze of SME and Management" Tirana 2015, pp 24)

Bankruptcy proceedings has quick character of the procedure for the property which is owned by the failed debtor which may occasionally lose its value, for the purpose of insolvency proceedings which has quick character, efficient and with certain period.

Through main principles contained in this procedure and make sui generis of civil procedure has to do with the principle of legitimacy, on which failure procedure may be opened only under the conditions specified by law.

Where under Article 5 as conditions for the opening of failure proceedings, and as an essential element of the principle of legitimacy presented paragraph 2 of Article 5 ever failed debtor is unable to pay for a period of 45 days from when the invoice or is created an obligation, where that has been particular carrier of payment, where that is not paid in fixed amount that should be paid under the obligation created.

Today the bankruptcy procedure is defined as the state where the debtor can not fulfill its obligations towards creditors bankruptcy where the other side is approaching execution of creditors' claims against the assets of the creditor where such a situation may lead to the loss of legal subjectivity failure debtor.

Based on the law on commercial companies it is predicted cases where the company may be at the opening of failure proceedings or capital company has entered in failure procedure that according to Article 13 of the law on commercial companies which is specified that problem. where according to this article is noted "that can not be registered as sole proprietor or individual upon who, (1), on which is open failure proceedings, (2).

On which the final court decision is confirmed that is opened failure, because could not perform the requests to creditors until the prohibition last for performing the activity that is certified by judicial decision, (3) which is in the competence of the body, according to the law, was forbidden to exercise activities under this law for the duration of prohibition. ${ }^{6}$

According to the law is given the vacant importance of the opening of Bankruptcy, proceedings and all commercial companies over which the insolvency proceeding are obliged to register traders noted that these are commercial company failure, or liquidation, the purpose of this Article the commercial Law has to do with the protection of the companies which are present in the market in order not to tie binding commercial relations that are in financial distress and is a kind of preventive measure. (Dumi A "Analyze of SME and Management" Tirana 2015, pp 112)

It also has to do with the protection of free competition between companies and the identification of companies that are in failure proceedings or on to open failure proceedings is the decision of the competent authority for initiating a procedure or when certain Commercial companies which are in the process of liquidation and the protection of other entities in order to be careful in relation to the establishment of contractual relations with these business entities.

\footnotetext{
${ }^{5}$ A. Jashari. "Subjects of business law "p: 337 Tetovo 2012.

5Dumi A "Analyze of SME and Management" Tirana 2015

6Dumi A "Analyze of SME and Management" Tirana 2015, pp 239

Law on commercial companies Article 13 "Official Newspapers of RM" No. 28/04
} 


\subsection{Law Treatment of Failure Procedure.}

Legal and legislative basis of failure proceedings, now is considered as the backbone of the operation of the legal system and free economy in capitalist systems against those who have concentrated capital in the state, by means of these laws placed an order in the economic circulation in order to show which commercial companies are capable of standing to market.

The first law on bankruptcy law passed in the Netherlands in 1515, which in this period is considered as a global center of commerce, the law passed in England has provided for the first time today based on the principle that collective compensation insolvency creditors has a great impact on the development of insolvency that has been Bancrupcy reform Act of 1978 of the US in which the first was scheduled reorganization as measure to stop the insolvency, whereas in English law Insolvencu Act 1986. In Albania we have in 2002 bankruptcy law, in Kosovo we have the law on liquidation and failure of legal persons in the event of insolvency in 2003, in Croatia there is bankruptcy law in 1996, in Germany we Insolvenzordining 1994. ${ }^{7}$

Bankruptcy as a very important legal notion as previously noted there was a considerable importance in the capitalist countries and advanced capital in the international plane, Holland since 1515 has developed the first norms in the sphere of insolvency given the geo-political circumstances that existed, and a well established principle,today recognized on the right of collective meeting the requirements insolvency creditors in bankruptcy measure opening. Then taking into account the commercial legal practice was necessary to establish the legal norm by specifying and solve problems that have been created such as the creation of a legal institutes such as the reorganization of companies as a form of bankruptcy that preventive measures today in this period where there is no security and the global financial crisis is very necessary to take such action as a preventive for not filling a financial crunch of certain states.

In the period 2012 to Macedonia in 2121 initiated bankruptcy proceedings of which are reorganized 7 subjects that have opened bankruptcy, and are closed about 834 business entities. ${ }^{8}$

On the basis of these data issued by the Central Register leak that during 2013, there were more initiated bankruptcy proceedings, and to a large volume, where that can be taken into account factors that outgrow the International economic climate where Macedonia and medium economies have suffered from the international financial crisis, if the impact of foreign investment if the foreign indirect investment.

After the proposal and meeting the conditions prescribed by law for the opening of bankruptcy proceedings and fulfillment of the essential elements of the proposal, but also the stage when the judge decides that the proposal but edha tance procedural aspect in the material in this case the judge passes the next phase of development procedure.

Judge who decides to accept the proposal for the opening of proceedings after the procedural action, the judge in the decision to open the proceedings, the judge can appoint a temporary director bankruptcy, then judge calls judicial hearing bankruptcy creditor and debtor about their requirements and objections that may arise in connection with the opening procedure.

:With the opening of the procedure bankruptcy judge in coordination with the interim director bankruptcy organize a session with a public announcement, as presented creditors and bankruptcy debtors and third persons that have legal interest judge examines applications of creditors which demand divided into two groups :

a) Creditors' demand which are confirmed by final decisions.

b) Creditors' demand which are not confirmed by final decisions.

The demands of creditors which are certified by the final decisions in the first judge finds that these decisions are consistent with the legal interest of the opening of the procedure but should certain them whether dealing with the same subject of trade which is open to the procedure.In cases when demands of creditors who appear at the hearing and at the opening of proceedings and to bankruptcy measure, but when these claims are not confirmed by the final decisions, bankruptcy judge does not accept such claims and sends the request to certify the procedure litigation and then to present it in front of a bankruptcy procedure. After reviewing the requirements proposed in bankruptcy proceedings, the bankruptcy judge appoints an economic expert to do any analysis regarding Active and Passive assets and property of the bankruptcy debtor, then the expert will present a financial report about the wealth of debtor and then send them to a bankruptcy judge.

As the concept of insolvency proceedings and legal institute in itself includes the protection of creditors, but also at

\footnotetext{
7 Jashari A. "Business entities of law," p. 537 Tetovo 2012

${ }^{8}$ The data were taken from the Central Register of the Republic of Macedonia with nr Arkivor 08-3117 / 3 
the same time has to do with the protection of debtors and determines how the rules can be implemented in mutual demands between subjects of law, bankruptcy proceedings in our system legal is made known to the transformation of companies, and new legal institutes was difficult at first prior to implementation and judicial practice.

If we take into account the chronological aspect of the insolvency proceedings given the socialist system that has been ion state but also the Balkan countries, the bankruptcy procedure has been the one unknown institutes but also taboo in some countries of the socialist system, so that as the institute and legal norm has been forbidden by law the bankruptcy of companies (SOE).

These commercial companies although they meet all the essential elements for the initiation and opening of bankruptcy proceedings are not such procedures as the fact that all the losses of the seller are covered by the main founder of the companies but also the only founder.

In the context of bankruptcy proceedings exist even a special branch and particular forms of insolvency and as such are well known in the legal literature but also on the basis of the law on bankruptcy, such as operating and developed within entities fixed and fixed content.

As a separate procedures are accounted international bankruptcy, insolvency against property to the deceased, bankruptcy to spouses, are counted as separate procedures for the fact that in these proceedings it comes to wealth which did not enter or they go into bankruptcy and the extent to which certain individual under the law have rights over the property of bankruptcy and in this way to achieve the fulfillment of creditors' claims against the above mentioned categories need special form of procedure for the realization of the rights of creditors in bankruptcy proceedings.

As a special form is the procedure which takes place on the property of a deceased person i.e individual trader on his property if there is a right of any creditor acquired after his death and the creditor may require performance by the legacy of heritage heritage which wealth has entered into bankruptcy measure, given the procedure that must be followed according to the legal provisions of the insolvency. In cases when there's a special need to prosecute the bankruptcy proceedings against the property of the common property spouses who may have come into bankruptcy and the extent to which there are certain requirements and separate to that common property of spouses or in cases when spouses have agreed an agreement and dispose of property part of bankruptcy and realization measure and for the opening procedure is followed a separate procedural actions in certain cases.Also in international bankruptcy cases as a special form of insolvency procedure which is needed at a time when the opening of the insolvency procedure set when the creditor estate or other state-related bankruptcy need international legal tool to develop an adequate procedure of bankruptcy, where in this procedure requires procedural actions which do not usually follow the normal procedure of bankruptcy, procedural actions in the form of the procedure are the implementation of international treaties in relation to the development of bankruptcy proceedings and recognition of documents of foreign states on conditions and reciprocity among states in respect of the bankruptcy proceedings.

\section{References}

International Standards, October 2011

GJEDNJ, 13 Nëntor 2007; kërkesa nr. 3371/02

Resolution of the Conference of European Ministers of Justice, 4 to 5 October 2001.Taken from the recommendation of the Committee on Legal Co-operation on the implementation of judgments of the member states of the Council of Europe..

"The Constitution of the Republic of Albania " Tirana 1998, pp 78-91

"Guides stones-jurisprudence of the European Court of Human Rights" Tirana 2000.Vol 1 p. p 198

"Guides stones-jurisprudence of the European Court of Human Rights" Tirana 2000.Vol 1fq 198

"Law court and the Convention of the Rights of Man "European University Centre of Warsaw vol 2, 2001 pp 19-21

"For a European public order; Selected decisions are the European court of human Rights Tirana2000,Vol I ,pp 7

"For a European public order". Selected decisions are the European court of human rights". Tirana 2000,Vol I, pp 289

"For a European public order". Selected decisions are the European court of human rights". Tirana 2000 I, pp 22

"Vienna Convention on the Law of Treaties" VLC Vienna, Austria 1980 pp 89-91 